Article

\title{
Employees' Perceptions of Corporate Social Responsibility and Job Performance: A Sequential Mediation Model
}

\author{
Inyong Shin ${ }^{1}$, Won-Moo Hur ${ }^{1}$ and Seongho Kang ${ }^{2, *}$ \\ 1 College of Business Administration, Pukyong National University, 45 Yongso-ro, Nam-gu, Busan 48513, \\ Korea; shiny@pknu.ac.kr (I.S.); wmhur@pknu.ac.kr (W.-M.H.) \\ 2 College of Business, Chosun University, 309 Pilmundae-ro, Dong-gu, Gwangju 61452, Korea \\ * Correspondence: shkang123@chosun.ac.kr; Tel.: +82-62-230-6836; Fax: +82-62-226-9664 \\ Academic Editor: Giuseppe Ioppolo \\ Received: 3 February 2016; Accepted: 16 May 2016; Published: 20 May 2016
}

\begin{abstract}
In spite of the increasing importance of corporate social responsibility (CSR) and employee job performance, little is still known about the links between the socially responsible actions of organizations and the job performance of their members. In order to explain how employees' perceptions of CSR influence their job performance, this study first examines the relationships between perceived CSR, organizational identification, job satisfaction, and job performance, and then develops a sequential mediation model by fully integrating these links. The results of structural equation modeling analyses conducted for 250 employees at hotels in South Korea offered strong support for the proposed model. We found that perceived CSR was indirectly and positively associated with job performance sequentially mediated first through organizational identification and then job satisfaction. This study theoretically contributes to the CSR literature by revealing the sequential mechanism through which employees' perceptions of CSR affect their job performance, and offers practical implications by stressing the importance of employees' perceptions of CSR. Limitations of this study and future research directions are discussed.
\end{abstract}

Keywords: perceived CSR; organizational identification; job satisfaction; job performance

\section{Introduction}

In response to societal pressure and ethical obligations, many firms have made efforts to play their part in socially responsible actions, leading to increasing interest from both scholars and practitioners in this particular area [1,2]. A growing body of literature suggests that an organization's involvement in corporate social responsibility (CSR) policies and practices tends to contribute not to only financial outcomes at the organizational level, but also to nonfinancial outcomes such as the firm's reputation in the eyes of its consumers and its attractiveness to investors by satisfying external stakeholders' expectations [3-6].

Despite increasing scholarly attention on the effects of CSR, there has been a lack of research effort in adopting an individual approach and focusing on internal stakeholders [7,8]. In particular, previous research has tended to neglect the possibilities that the CSR activities of organizations might affect the job performance of their members at the individual level $[9,10]$. This is surprising and unfortunate, not only because employees constitute the critical internal stakeholders who play pivotal roles in organizations, but also because their performance forms the building block for organizational survival and prosperity [7]. To close this gap, we focus on the effect of CSR on job performance at the individual level.

Further, a review of the CSR-related literature posits that it is imperative to address the underlying mechanisms through which CSR policies lead to particular outcomes at the individual level $[9,10]$. 
The present study thus focuses on an exploration of the various intervening variables so as to identify the potential processes between organizational social responsibility and individual job performance. It is noticeable that, in the case of complex relationships between independent and dependent variables, change in one mediator might cause change in another mediator, which requires the examination of the sequential mediation relationships as a better way for understanding potential links between all variables $[11,12]$. We therefore attempt to comprehensively establish how employees' perceptions of CSR are related to their job performance by considering a sequential mediation chain.

The present study is expected to contribute to the literature in at least two ways. First, we pay attention to a relationship between organizational social responsibility and individual job performance. This will allow us to reveal the role of CSR in explaining levels of job performance of organizational members as principal internal stakeholders. Second, we develop a sequential mediation model for fully understanding how perceived CSR is related to job performance. This study unfolds the underlying mechanisms that link CSR with outcomes at the individual level by explicating that attitudes toward organizations and jobs (i.e., organizational identification and job satisfaction) intervene in a series between perceived CSR and job performance.

\section{Theory and Hypotheses}

\subsection{Theoretical Framework}

Although consensus on a precise definition has yet to be found, it is broadly accepted that CSR refers to organizational actions that take into account stakeholders' expectations in economic, social, and environmental contexts [9]. Over the last decades, companies have come under growing pressure to actively pursue CSR efforts from a variety of stakeholders [13]. Firms engaging in CSR thus exhibit philanthropic and socially responsible business practices beyond the pursuit of their economic self-interest and compliance with the law $[1,8,14]$. Further, it is known that these firms tend to take financial and reputational benefits from socially responsible behaviors [15].

CSR has drawn increasing attention from scholars, however, the effects that organizations' CSR efforts have on their members have remained somewhat understudied [1,15]. In order to discuss the impacts of CSR activities on employees, it is first required to determine the level of analysis. Because people tend to behave according to their perceptions of what reality is rather than reality itself [16], perception is recognized as an important driving force leading to an individual's behavior. Accordingly, how organizational members perceive the CSR actions of their organization seems to be significant in understanding its effects at the individual level. Some scholars argued that we should pay attention to the role of perception so as to understand the impact of organizations' CSR behaviors on their employees, in that belief about organizations' involvement in CSR activities could elicit individual responses to work (e.g., $[15,17])$. This study thus focuses on employees' perceptions of the CSR implemented by the organization to which they belong, and defines perceived CSR as the degree to which employees perceive whether their organization takes part in CSR policies and practices [2].

CSR incorporates various responsibilities for the circumstances surrounding a company rather than plans to maximize its profit. Most firms do not engage in CSR activities as a means to facilitate the performance of their members (e.g., human resource management practices and leadership styles). That is why it is intuitively difficult to believe that employees' perceptions of CSR are likely to directly influence their job performance. Rather, it is reasonable to anticipate that employees' perceptions of CSR would affect their psychological states or work attitudes, which in turn would influence their job performance. We thus need to explore mediators that could account for the underlying processes through which perceived CSR is able to be related to job performance [9]. At this time, organizational identification theory seems to be helpful in bridging the link between perceived CSR and job performance. Derived from social identity theory and self-categorization theory, organizational identification refers to the psychological connection between the definition of an organization and the definition of an employee [18]. Much of the organizational identification literature stated that when 
employees perceive their organization's image to be attractive, they tend to have strong identification with the organization [18,19]. Previous research has shown that employees are inclined to identify with an organization that generates positive values through its CSR activities [7,20]. Further, since individuals who feel a strong sense of belonging to their organization tend to be motivated to achieve its goals and to exert much effort, it is theoretically likely that employees holding strong organizational identification exhibit enhanced effectiveness at work $[19,21,22]$. We thus regard organizational identification as a primary mediator between perceived CSR and job performance.

However, there is no clear empirical evidence for a relationship between organizational identification and job performance. Prior studies have failed to demonstrate the main effect of organizational identification on in-role performance [7], or have found only a weak correlation between them [23]. Considering these results from previous research, it might be beneficial to investigate the underlying process through which organizational identification influences job performance rather than the direct effect that organizational identification has on job performance [20]. Scholars posit that one of the critical factors explaining work outcomes such as task achievement could be the level of satisfaction they have with their current jobs [24,25], which is generally a central consideration in the research that examines employee-based phenomena [26]. We thus anticipate that job satisfaction, which refers to an evaluative state that expresses contentment with and positive feelings about one's job [27], would more immediately enhance job performance than would organizational identification. With the expectation that job satisfaction would play a mediating role through which organizational identification affects job performance, this study suggests job satisfaction as a subsequent mediator between perceived CSR and job performance.

In sum, as depicted in Figure 1, it is expected that there will be serial relationships between perceived CSR, organizational identification, job satisfaction, and job performance. We propose that employees who believe that their organization takes socially responsible actions are likely to perform their jobs well, firstly because they identify strongly with their organization, and secondly due to their satisfaction with their job. In order to develop the sequential mediation model to explain how employees' perceptions of CSR influence their job performance, we will first examine the specific links between each variable based on the theoretical reasoning and empirical results, and will then suggest a sequential mediation chain by fully integrating these links.

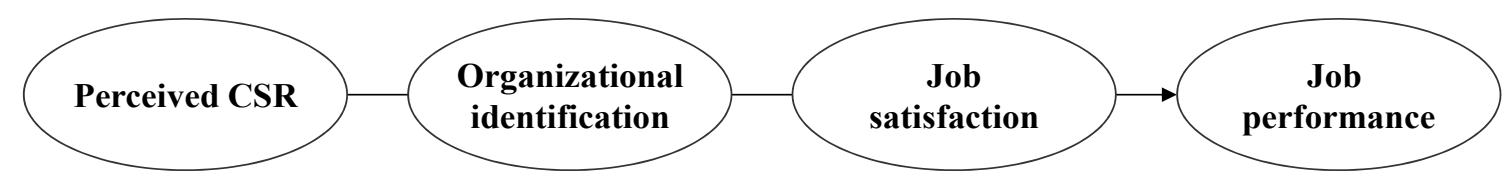

Figure 1. Research model.

\subsection{Hypothesis Development}

Organizations serve as social systems where organizational members define their self-concept [20]. Organizational identification theory suggests that when employees regard the identity of their organization as being distinctive and favorable, and further integrate it with their self-concept, they are inclined to develop strong identification with the organization $[18,28]$. Recognizing the conceptualization of organizational identification as a fluid and dynamic construct rather than a stable and fixed one, scholars have paid attention to exploring factors to determine employees' organizational identification [15,29].

Applying this reasoning to CSR, employees are able to be attracted to the socially responsible actions of their organization because CSR activities provide them with a sense of worth and an opportunity to achieve a higher purpose in the workplace [30]. In particular, when employees perceive that their organization actively presents policy initiatives for social development and continuously 
participates in socially responsible actions, it is highly likely that these perceptions enhance the degree to which they feel attached to the organization to which they belong. In this regard, some scholars argued that the more positively employees perceive the image of their organization's CSR, the stronger their organizational identification is [15]. Other researchers have extended this argument by demonstrating that employees working for companies engaged in CSR tend to experience high levels of organizational identification [7,31]. Further, it has been found that favorable perceived organizational prestige in the form of CSR performance is more highly associated with employee's identification with their organization, compared to favorable perceived organizational prestige in terms of market and financial performance [20].

Based on the above discussion, we expect that employees' perceptions that their company engages in socially responsible actions would increase the level of their organizational identification. We thus put forward the following hypothesis:

\section{H1: Perceived CSR is positively related to organizational identification.}

Organizational identification has a potential to produce positive employee outcomes in the workplace. Organizational identification encourages employees to have strong and enduring relationships with their organization based on a feeling of belongingness to and a sense of oneness with the organization [28,32]. Further, these employees tend to be emotionally and cognitively immersed in their organization, which results in more positive attitudes toward their own job [18,32].

Given that job satisfaction is developed from employees' interpretations of the job circumstances, employees with strong organizational identification positively evaluate their job characteristics and perceive their job as proof of their organizational membership and as validating those parts of their self that stem from this membership [33]. Consistent with this reasoning, prior studies have found that employees being strongly identified toward their organization tend to exhibit constructive attitudes toward their job for improving in-role performance [33,34].

Based on the preceding discussion, we expect that organizational identification would function as an antecedent of job satisfaction, and advance the following hypothesis:

H2: Organizational identification is positively related to job satisfaction.

It is broadly accepted that happier workers are more likely to be productive than less happy ones [16]. Individuals with high levels of job satisfaction hold positive feelings about their job, and in turn are motivated to strive to perform well by increasing work quality and quantity. Researchers in the fields of organizational behavior and industrial-organizational psychology have been long interested in the effects of job satisfaction in the workplace [27]. Indeed, a review of prior cross-sectional studies has found that there is a substantial relationship between job satisfaction and job performance [35]. In addition, further research has meta-analyzed the link between them to examine the causality issue regarding whether job satisfaction leads or is led by job performance, and has found that the satisfaction-to-performance relationship is stronger than the performance-to-satisfaction relationship [36].

As a result, job satisfaction, being the pleasurable state resulting from the appraisal of one's job or job experiences, is likely to function as a strong predictor of job performance [25]. We thus suggest the following hypothesis:

\section{H3: Job satisfaction is positively related to job performance.}

The theoretical arguments of this study so far suggest that employees' perceptions of their organization's socially responsible actions as being good to encourage them to identify with the organization, which in turn increases their satisfaction with their job, eventually leading to superior job performance. This implies that there seem to be multicomponent interventions (i.e., organizational 
identification and job satisfaction) between employees' perceptions of CSR and their job performance, requiring us to identify roles of multicomponent interventions in explaining the relationship between the predictor and the outcome by developing a sequential mediation model [11,12]. Hence, it is desirable to suggest and test the sequential mediation chain so as to accurately understand how perceived CSR has an effect on job performance.

It is expected that organizational identification and job satisfaction would act as serial mediators in the link between perceived CSR and job performance. We thus put forward the following hypothesis:

H4: Perceived CSR is indirectly and positively related to job performance, sequentially mediated through first organizational identification and then job satisfaction.

\section{Methodology}

\subsection{Data Collection and Participant Characteristics}

For the purposes of our study, we decided to collect data from hotel employees in South Korea. Kim et al. [37] note that as a leading industrial trading country within the Western sphere and therefore "highly subject to global isomorphic pressures", South Korean society nonetheless "adheres to Confucian vales of collectivism, informal virtue, and morality". As a result, South Korean organizations suffer from much strain between society's Confucianism and the Anglo-American values, organization systems and business conditions from which CSR concepts originated [37,38]. In this unique setting, there is considerable scope for discussion about the role of employees' perceptions of CSR, making South Korean employees an interesting subject group for this study. Furthermore, we selected the hotel industry, which is known to be sensitive to changes and trends in its operating environment [39], making it especially responsive to changes arising from CSR issues.

Employees of four luxury hotels in South Korea were surveyed in June-July 2014 using a self-administered instrument for data collection. A total of 480 employees were invited to participate in this study. They were asked to complete a self-report questionnaire which was to be returned to the researchers directly using pre-addressed envelopes, thus ensuring confidentiality. A total of 255 responses were received, from which 250 usable responses were obtained after list-wise deletion, representing a response rate of $52.1 \%$. Based on these 250 responses, a preliminary analysis revealed that $61.8 \%$ of the respondents were male, with an average age of $33.65(\mathrm{SD}=8.07)$ years. A majority of the participants $(45.4 \%)$ had a university education, and the respondents, on average, had 8.93 $(\mathrm{SD}=6.47)$ years of work experience.

\subsection{Measurement Scales}

To measure all the constructs in this study, we adopted existing well-established scales (see Table 1). The five-point Likert-type scales ranged from 1 ("strongly disagree") to 5 ("strongly agree"). Since the selected scales were English-based, a double translation method was required. The translation of the English questionnaire into Korean followed the process recommended by Brislin [40], and vice versa. Perceived CSR was measured using three items adjusted from Du et al. [41] and Wagner et al. [42]. To measure organizational identification, we relied on four items developed by Mael and Ashforth [21]. Job satisfaction was measured using four items adopted from Cho et al. [43]. To measure job performance, we used four items adopted from Liao and Chuang [44].

In testing the hypotheses, we controlled for age (in years), gender, and job tenure (in years) because they were found to affect the levels of employees' organizational identification (e.g., [20,45]), job satisfaction (e.g., [46-48]), and job performance (e.g., [49,50]). 
Table 1. Scale items and construct evaluation.

\begin{tabular}{|c|c|c|c|c|c|}
\hline Construct & Item & $\lambda^{a}$ & $\alpha^{b}$ & $\mathrm{CR}^{\mathrm{c}}$ & $\operatorname{AVE}^{d}$ \\
\hline $\begin{array}{l}\text { Perceived corporate } \\
\text { social responsibility } \\
\text { (CSR) }\end{array}$ & $\begin{array}{l}\text { This organization is a socially responsible company (hotel). } \\
\text { This organization is concerned with improving the well-being of society. } \\
\text { This organization behaves responsibly regarding the environment. }\end{array}$ & $\begin{array}{l}0.75 \\
0.84 \\
0.78\end{array}$ & 0.83 & 0.83 & 0.63 \\
\hline $\begin{array}{c}\text { Organizational } \\
\text { identification }\end{array}$ & $\begin{array}{l}\text { I am very interested in what others think about this organization. } \\
\text { When I talk about my organization, I usually say "we" rather than "they". } \\
\text { This organization's successes are my successes. } \\
\text { When someone praises this organization, it feels like a personal compliment. }\end{array}$ & $\begin{array}{l}0.70 \\
0.77 \\
0.83 \\
0.80\end{array}$ & 0.86 & 0.86 & 0.60 \\
\hline Job satisfaction & $\begin{array}{l}\text { My job is very pleasant. } \\
\text { My job is very worthwhile. } \\
\text { My job is better than most. } \\
\text { I am very content with my job. }\end{array}$ & $\begin{array}{l}0.81 \\
0.84 \\
0.73 \\
0.83\end{array}$ & 0.88 & 0.88 & 0.65 \\
\hline Job performance & $\begin{array}{l}\text { I am friendly and helpful to customers. } \\
\text { I approach customers quickly. } \\
\text { I ask good questions and listen to find out what a customer wants. } \\
\text { I am able to help customers when needed. }\end{array}$ & $\begin{array}{l}0.80 \\
0.81 \\
0.80 \\
0.78\end{array}$ & 0.88 & 0.88 & 0.64 \\
\hline
\end{tabular}

\section{Results}

\subsection{Reliability, Validity, and Common Method Bias}

The measurement scales were subjected to a commonly used validation process to assess their reliability, validity, and unidimensionality. The reliability of the constructs was evaluated using Cronbach's alpha coefficients (see Table 1 ), which were shown to range from 0.83 to 0.88 , which was considered satisfactory [51]. Using M-plus 7.31 software, we verified the convergent and discriminant validity of the measurement items through confirmatory factor analysis (CFA).

The measurement model fit well with the data of this study as seen in the fit statistics for the model $\left(\chi^{2}{ }_{(84)}=97.85 ; p>0.05\right.$, CFI $($ The Comparative Fit Index $)=0.98$, TLI (the Tucker Lewis Index $)=0.99$, RMSEA (The Root Mean Square Error of Approximation) $=0.03$, SRMR (Standardized Root Mean Square Residual $=0.03$ ). Across our measurement model, the factor loadings of all the items exceeded 0.70 , with all the $t$-values greater than 2.58 , providing evidence of convergent validity among our measures. All the measures exhibited strong reliability, with composite reliabilities ranging from 0.83 to 0.88 (see Table 1). In addition, we checked the condition for discriminant validity among constructs suggested by Fornell and Locker [52]. All average variance extracted (AVE) values of constructs were found to be larger than the squared correlation between the construct and any others (see Table 2). Overall, our constructs exhibited sound measurement properties.

Table 2. Means, standard deviations, and correlations among constructs.

\begin{tabular}{lcccccc}
\hline \multicolumn{1}{c}{ Construct } & Mean & SD & $\mathbf{1}$ & $\mathbf{2}$ & $\mathbf{3}$ & $\mathbf{4}$ \\
\hline 1. Perceived CSR & 3.54 & 0.69 & 0.63 & & & \\
2. Organizational identification & 3.72 & 0.76 & $0.57^{* *}$ & 0.60 & & \\
3. Job satisfaction & 3.74 & 0.69 & $0.46^{* *}$ & $0.47^{* *}$ & 0.65 & \\
4. Job performance & 4.00 & 0.67 & $0.37^{* *}$ & $0.46^{* *}$ & $0.67^{* *}$ & 0.64 \\
\hline
\end{tabular}

Note: The number in the diagonal is the AVE; ${ }^{* *} p<0.01$.

Most researchers agree that common method variance (CMV) poses a potentially serious threat of bias in behavioral research, especially with single-informative surveys [53]. According to the method used by Podsakoff et al. [53], bias can be controlled through both procedural and statistical remedies. We introduced procedural remedies by protecting respondents' anonymity and separating the measurement of the predicting and outcome variables. We also applied the following statistical remedy. We used a confirmatory factor analytic approach based on Harman's single-factor analysis. 
The fit indices indicated a worse fit for the one-factor model compared to our measurement model $\left(\chi^{2}{ }_{(90)}=822.85 ; p<0.05, \mathrm{CFI}=0.63, \mathrm{TLI}=0.57, \mathrm{RMSEA}=0.18, \mathrm{SRMR}=0.12\right)$. We thus consider that common method bias was non-problematic in the case of this dataset.

\subsection{Hypothesis Testing}

Our structural model fit the data well $\left(\chi^{2}{ }_{(120)}=157.55 ; p<0.05\right.$, CFI $=0.98$, TLI $=0.98$, RMSEA $=0.04$, SRMR $=0.04)$. The hypothesized structural model did explain variance in organizational identification $\left(R^{2}=33.2 \%\right)$, in job satisfaction $\left(R^{2}=32.0 \%\right)$, and in job performance $\left(R^{2}=48.1 \%\right)$. We estimated all of the path coefficients (see Table 3 ). The analyses provided support for Hypothesis 1, predicting that perceived CSR would be positively related to organizational identification $(b=0.58, p<0.01)$. In addition, organizational identification was a significant predictor of job satisfaction ( $b=0.33, p<0.01)$, supporting Hypothesis 2 . Further, job satisfaction was positively associated with job performance, providing support for Hypothesis 3 ( $b=0.50, p<0.01)$.

Table 3. Path coefficients and indirect effects for mediation models.

\begin{tabular}{|c|c|c|c|c|c|c|c|}
\hline & \multicolumn{4}{|c|}{ Path Coefficient } & \multicolumn{3}{|c|}{ Indirect Effects } \\
\hline & CSR & OI & JS & $\mathbf{J P}$ & Estimate & $\mathrm{CI}_{\text {low }}$ & $\mathrm{CI}_{\text {high }}$ \\
\hline \multicolumn{8}{|l|}{ From $\rightarrow$ To } \\
\hline CSR & & $0.58^{* *}$ & $0.33^{* *}$ & 0.02 & & & \\
\hline OI & & & $0.33^{* *}$ & $0.19^{*}$ & & & \\
\hline JS & & & & $0.50 * *$ & & & \\
\hline $\begin{array}{l}\text { Total Indirect Effect } \\
\text { Indirect Effect }\end{array}$ & & & & & $0.37 *$ & 0.24 & 0.55 \\
\hline $\mathrm{CSR} \rightarrow \mathrm{OI} \rightarrow \mathrm{JP}$ & & & & & $0.11 *$ & 0.01 & 0.22 \\
\hline $\mathrm{CSR} \rightarrow \mathrm{JS} \rightarrow \mathrm{JP}$ & & & & & $0.16^{*}$ & 0.07 & 0.32 \\
\hline $\mathrm{CSR} \rightarrow \mathrm{OI} \rightarrow \mathrm{JS} \rightarrow \mathrm{JP}$ & & & & & $0.10 *$ & 0.04 & 0.18 \\
\hline \multicolumn{8}{|l|}{ Direct Effect } \\
\hline $\mathrm{CSR} \rightarrow \mathrm{JP}$ & & & & & 0.02 & -0.16 & 0.19 \\
\hline Total Effect & & & & & & & \\
\hline $\mathrm{CSR} \rightarrow \mathrm{JP}$ & & & & & $0.39 *$ & 0.26 & 0.54 \\
\hline
\end{tabular}

Note: CSR: perceived CSR; OI: organizational identification; JS: job satisfaction; JP: job performance; ${ }^{*} p<0.05$, ** $p<0.01 ; \mathrm{CI}=95 \%$ confidence level (bootstrapping).

In order to test the sequential mediation hypothesis, we used a serial multiple mediated model $[54,55]$. This mediation approach directly tests the indirect effect between the independent and the dependent variables through serial multiple mediators via a bootstrapping procedure $(\mathrm{N}=5000)[56,57]$. Hypothesis 4 stated that employees' organizational identification and job satisfaction would sequentially mediate the relationship between perceived CSR and their job performance. As shown in Table 3, the results of the analysis indicated that perceived CSR was positively associated first with organizational identification and then job satisfaction, which was positively related to job performance $\left(b=0.10,95 \% \mathrm{CI}_{95} \%\right.$ confidence level $\left.[0.04,0.18]\right)$. Furthermore, the direct relationship between perceived CSR and job performance was not statistically significant $(b=0.02, p>0.05)$. In sum, we confirmed that the positive relationship between perceived CSR and job performance was fully and sequentially mediated by organizational identification and job satisfaction.

\section{Discussion}

The objective of this study was to develop a sequential mediation model to explain how employees' perceptions of CSR influence their job performance. In particular, we focused on attitudes at work in order to identify the underlying mechanisms between perceived CSR and job performance. More specifically, this study first examined the hypotheses regarding the specific links between perceived CSR, organizational identification, job satisfaction, and job performance, and investigated a sequential 
mediation chain by fully integrating these links. The results of this study offered strong support for our hypotheses. We found that perceived CSR was indirectly and positively associated with job performance sequentially mediated first through organizational identification and then job satisfaction.

\subsection{Theoretical Contributions and Managerial Implications}

This study offers a theoretical model for explaining the link between organizational social responsibilities and individual job performance, and provides empirical evidence for the relationship. The current study contributes to the relevant theoretical literature and has important implications for managers.

Although the CSR activities of organizations and the job performance of employees as the principal internal stakeholders are recognized to be significant [8], research regarding the effect of CSR on job performance has received little attention. A few studies have attempted to examine whether employees' perceptions of CSR influence their job performance (e.g., $[7,20])$, however, they have not provided clear evidence of the relationship. To address this research gap, we concentrated on how perceived CSR would be related to job performance. More specifically, reflecting the argument of some scholars that it is imperative to clearly explicate the relationship between CSR and particular outcomes at the individual level $[9,10]$, this study has attempted to extend previous research by revealing the underlying mechanisms through which employees' perceptions of CSR influence their job performance. In other words, this study highlights that employees' perceptions of organizational social responsibilities enhance their job performance, not directly but indirectly, by influencing the intervening variables. We have suggested that organizational identification and job satisfaction act as serial mediators in the link between perceived CSR and job performance. Our findings indicate that when employees perceive that their organization takes part in socially responsible actions, they are more likely to identify with their organization. Further, this identification toward their organization tends to translate into satisfaction with their own job, leading to enhanced levels of job performance. By identifying the serial mediating roles of organizational identification and job satisfaction in the link between employees' perceptions of CSR and their job performance, this study contributes to the theoretical development of the CSR literature that until now has not clearly provided clear routes from perceived CSR to job performance.

This study also suggests practical recommendations for managers in today's business organizations. Specifically, managers should concern themselves with employees' perceptions of organizational CSR activities. As stressed above, individuals tend to behave according to their perceptions of what reality is [16]. Since employees' subjective perceptions of their organization seem to be crucial for positive employee outcomes [58], managers should fully understand how their members interpret and respond to organizational CSR policies. It is basically meaningful that organizations develop and implement socially responsible policies and practices, however, it might be more significant to inform organizational members about CSR efforts. It is thus advisable that organizations communicate their CSR activities in order to strengthen employees' attitudes toward their organization and job $[24,59,60]$. According to the findings of this study, CSR behaviors play a pivotal role in fostering employees' organizational identification and job satisfaction, and consequently job performance. In other words, organizational identification determined by perceived CSR tends to improve levels of job satisfaction, which could be usefully used as an important checkpoint for enhancing the job performance of their members. As a result, it would seem sensible to actively promote the organization's actual CSR practices or to continuously emphasize organizational policies reflecting social responsibility.

\subsection{Limitations and Future Research Directions}

Although this study offers important contributions and implications, several limitations should be borne in mind and ideally resolved by future research. First, this study used self-reported scales for the constructs. While we applied procedural and statistical methods in order to minimize concerns about 
common method bias [53], it still remains possible to inflate the relationship between the antecedents and consequences due to the limitations of self-reported data. It is expected that future research would avoid the common method bias problem by collecting data from heterogeneous sources or by drawing on longitudinal designs. Second, this study focused on hotel employees and asked them to respond to the questionnaires. The specific nature of their work (i.e., service delivery) might influence the results of this study. Different from office or manufacturing workers, the level of their job performance is generally determined in interacting with customers. It is thus hoped that additional research will replicate our model with different samples, and that another scholar will additionally verify whether our results are extendable to other behavioral outcomes such as creative performance and organizational citizenship behavior. Third, this study did not separate the specific sub-dimensions of CSR [61]. Future research thus needs to identify the different roles of each sub-dimension of CSR (i.e., economic, legal, ethical, and philanthropic) so as to see whether these sub-dimensions have similar or different effects on employee outcomes. Fourth, we did not include boundary conditions that might affect the perceived CSR-organizational identification-job satisfaction-job performance relationship in the research model because of the need for model parsimony. Nonetheless, contextual factors might be potential moderators of the organizational CSR-individual outcomes relationship. Accordingly, other scholars would be advised to incorporate potential moderators such as organizational climate and leadership styles for a better understanding of how employees' perceptions of CSR are associated with their outcomes.

\section{Conclusions}

It has been recognized that the co-propensity of firms and the society where they are embedded is critical in today's business environment. In this regard, scholars have paid attention to organizations' CSR behaviors as an important way to bring about this mutual propensity. This study posits that benefits of CSR behaviors also exist inside an organization. When employees perceive that their organization strives to develop and implement socially responsible activities, they come to be identified with their organization and to be satisfied with their job, and consequently exhibit superior performance at work. The principal purpose of an organization's CSR investments is not to enhance internal effectiveness, however, employees' perceptions of CSR behaviors has been found to increase the returns on such behaviors in a roundabout way. The findings of this study therefore suggest that the win-win relationship of companies and their members through individual beliefs of organizational CSR policies and practices are able to be realized.

Acknowledgments: The study was supported by a 2015 research fund from Chosun University.

Author Contributions: Inyong Shin and Won-Moo Hur conceived and designed the research model of this paper; Won-Moo Hur analyzed the data; Inyong Shin and Seongho Kang reviewed the relevant literature; All authors wrote the manuscript and approved the final manuscript.

Conflicts of Interest: The authors declare no conflict of interest.

\section{References}

1. Bauman, C.W.; Skitka, L.J. Corporate social responsibility as a source of employee satisfaction. Res. Organ. Behav. 2012, 32, 63-86. [CrossRef]

2. Choi, Y.; Yu, Y. The influence of perceived corporate sustainability practices on employees and organizational performance. Sustainability 2014, 6, 348-364. [CrossRef]

3. Orlitzky, M.; Schmidt, F.L.; Rynes, S.L. Corporate social and financial performance: A meta-analysis. Organ. Stud. 2003, 24, 403-441. [CrossRef]

4. Peloza, J. The challenge of measuring financial impacts from investments in corporate social performance. J. Manag. 2009, 35, 1518-1541. [CrossRef]

5. Kim, H.; Hur, W.M.; Yeo, J. Corporate brand trust as a mediator in the relationship between consumer perception of CSR, corporate hypocrisy, and corporate reputation. Sustainability 2015, 7, 3683-3694. [CrossRef] 
6. Graves, S.B.; Waddock, S.A. Institutional owners and corporate social performance. Acad. Manag. J. 1994, 37, 1034-1046. [CrossRef]

7. Jones, D.A. Does serving the community also serve the company? Using organizational identification and social exchange theories to understand employee responses to a volunteerism programme. J. Occup. Organ. Psychol. 2010, 83, 857-878. [CrossRef]

8. McWilliams, A.; Siegel, D. Corporate social responsibility: A theory of the firm perspective. Acad. Manag. Rev. 2001, 26, 117-127.

9. Aguinis, H.; Glavas, A. What we know and don't know about corporate social responsibility: A review and research agenda. J. Manag. 2012, 38, 932-968. [CrossRef]

10. Rupp, D.E.; Mallory, D.B. Corporate social responsibility: Psychological, person-centric, and progressing. Annu. Rev. Organ. Psychol. Organ. Behav. 2015, 2, 211-236. [CrossRef]

11. Koning, I.M.; Maric, M.; MacKinnon, D.; Vollebergh, W.A.M. Effects of a combined parent-student alcohol prevention program on intermediate factors and adolescents' drinking behavior: A sequential mediation model. J. Consult. Clin. Psychol. 2015, 83, 719-727. [CrossRef] [PubMed]

12. Taylor, A.B.; MacKinnon, D.P.; Tein, J.Y. Tests of the three-path mediated effect. Organ. Res. Methods 2008, 11, 241-269. [CrossRef]

13. Brammer, S.; Millington, A.; Rayton, B. The contribution of corporate social responsibility to organizational commitment. Int. J. Hum. Resour. Manag. 2007, 18, 1701-1719. [CrossRef]

14. Kotler, P.; Lee, N. Corporate Social Responsibility: Doing the Most Good for Your Company and the Road Ahead; John Wiley: Hoboken, NJ, USA, 2005.

15. Glavas, A.; Godwin, L.N. Is the perception of 'goodness' good enough? Exploring the relationship between perceived corporate social responsibility and employee organizational identification. J. Bus. Ethics 2013, 114, 15-27. [CrossRef]

16. Robbins, S.P.; Judge, T.A. Organizational Behavior; Pearson Education Limited: Harlow, Essex, UK, 2015.

17. Valentine, S.; Fleischman, G. Ethics programs, perceived corporate social responsibility and job satisfaction. J. Bus. Ethics 2008, 77, 159-172. [CrossRef]

18. Dutton, J.E.; Dukerich, J.M.; Harquail, C.V. Organizational images and member identification. Admin. Sci. Quart. 1994, 39, 239-263. [CrossRef]

19. Dutton, J.E.; Dukerich, J.M. Keeping an eye on the mirror: The role of image and identity in organizational adaptation. Acad. Manag. J. 1991, 34, 517-554. [CrossRef]

20. Carmeli, A.; Gilat, G.; Waldman, D.A. The role of perceived organizational performance in organizational identification, adjustment and job performance. J. Manag. Stud. 2007, 44, 972-992. [CrossRef]

21. Mael, F.; Ashforth, B.E. Alumni and their alma mater: A partial test of the reformulated model of organizational identification. J. Organ. Behav. 1992, 13, 103-123. [CrossRef]

22. Tyler, T.R. Why people cooperate with organizations: An identity-based perspective. Res. Organ. Behav. 1999, 21, 201-246.

23. Riketta, M. Organizational identification: A meta-analysis. J. Vocat. Behav. 2005, 66, 358-384. [CrossRef]

24. De Roeck, K.; Marique, G.; Stinglhamber, F.; Swaen, V. Understanding employees' responses to corporate social responsibility: Mediating roles of overall justice and organizational identification. Int. J. Hum. Resour. Manag. 2014, 25, 91-112. [CrossRef]

25. Saari, L.M.; Judge, T.A. Employee attitudes and job satisfaction. Hum. Resour. Manag. 2004, 43, $395-407$. [CrossRef]

26. Spector, P.E. Job Satisfaction: Application, Assessment, Cause, and Consequences; Sage Press: Thousand Oaks, CA, USA, 1997.

27. Judge, T.A.; Kammeyer-Mueller, J.D. Job attitudes. Annu. Rev. Psychol. 2012, 63, 341-367. [CrossRef] [PubMed]

28. Ashforth, B.E.; Mael, F. Social identity theory and the organization. Acad. Manag. Rev. 1989, 14, $20-39$.

29. Gioia, D.A.; Schultz, M.; Corley, K.G. Organizational identity, image, and adaptive instability. Acad. Manag. Rev. 2000, 25, 63-81.

30. Aguinis, H.; Glavas, A. Embedded versus peripheral corporate social responsibility: Psychological foundations. Ind. Organ. Psychol. 2013, 6, 314-332. [CrossRef] 
31. De Roeck, K.; Delobbe, N. Do environmental CSR initiatives serve organizations' legitimacy in the oil industry? Exploring employees' reactions through organizational identification theory. J. Bus. Ethics 2012, 110, 397-412. [CrossRef]

32. Bhattacharya, C.; Korschun, D.; Sen, S. Strengthening stakeholder-company relationships through mutually beneficial corporate social responsibility initiatives. J. Bus. Ethics 2009, 85, 257-272. [CrossRef]

33. Van Dick, R.; Christ, O.; Stellmacher, J.; Wagner, U.; Ahlswede, O.; Grubba, C.; Hauptmeier, M.; Hohfeld, C.; Molzen, K.; Tissington, P.A. Should I stay or should I go? Explaining turnover intentions with organizational identification and job satisfaction. Brit. J. Manag. 2004, 15, 351-360. [CrossRef]

34. Van Knippenberg, D.; van Schie, E.C.M. Foci and correlates of organizational identification. J. Occup. Organ. Psychol. 2000, 73, 137-147. [CrossRef]

35. Judge, T.A.; Thoresen, C.J.; Bono, J.E.; Patton, G.K. The job satisfaction-job performance relationship: A qualitative and quantitative review. Psychol. Bull. 2001, 127, 376-407. [CrossRef] [PubMed]

36. Riketta, M. The causal relation between job attitudes and performance: A meta-analysis of panel studies. J. Appl. Psychol. 2008, 93, 472-481. [CrossRef] [PubMed]

37. Kim, C.H.; Amaeshi, K.; Harris, S.; Suh, C.J. CSR and the national institutional context: The case of South Korea. J. Bus. Res. 2013, 66, 2581-2591. [CrossRef]

38. Miles, L. The application of Anglo-American corporate practices in societies influenced by Confucian values. Bus. Soc. Rev. 2006, 111, 305-321. [CrossRef]

39. Rodríguez, F.J.G.; Cruz, Y.D.M.A. Relation between social-environmental responsibility and performance in hotel firms. Int. J. Hosp. Manag. 2007, 26, 824-839. [CrossRef]

40. Brislin, R.W. Back-translation for cross-cultural research. J. Cross Cult. Psychol. 1970, 1, 185-216. [CrossRef]

41. Du, S.; Battacharya, C.B.; Sen, S. Reaping relational rewards from corporate social responsibility: The role of competitive positioning. Int. J. Res. Mark. 2007, 24, 224-241. [CrossRef]

42. Wagner, T.; Lutz, R.J.; Weitz, B.A. Corporate hypocrisy: Overcoming the threat of inconsistent corporate social responsibility perceptions. J. Mark. 2009, 73, 77-91. [CrossRef]

43. Cho, Y.N.; Rutherford, B.N.; Park, J. Emotional labor's impact in a retail environment. J. Bus. Res. 2013, 66, 2338-2345. [CrossRef]

44. Liao, H.; Chuang, A. A multilevel investigation of factors influencing employee service performance and customer outcomes. Acad. Manag. J. 2004, 47, 41-58. [CrossRef]

45. Brammer, S.; He, H.; Mellahi, K. Corporate social responsibility, employee organizational identification, and creative effort: The moderating impact of corporate ability. Group. Organ. Manag. 2015, 40, 323-352. [CrossRef]

46. Kim, H. Transformational leadership, organizational clan culture, organizational affective commitment, and organizational citizenship behavior: A case of South Korea's public sector. Public Organ. Rev. 2014, 14, 397-417. [CrossRef]

47. Avolio, B.J.; Zhu, W.; Koh, W.; Bhatia, P. Transformational leadership and organizational commitment: Mediating role of psychological empowerment and moderating role of structural distance. J. Organ. Behav. 2004, 25, 951-968. [CrossRef]

48. Hartmann, N.N.; Rutherford, B.N.; Feinberg, R.; Anderson, J.G. Antecedents of mentoring: Do multi-faceted job satisfaction and affective organizational commitment matter? J. Bus. Res. 2014, 67, 2039-2044. [CrossRef]

49. Bowen, C.; Swim, J.K.; Jacobs, R.R. Evaluating gender biases on actual job performance or real people: A meta-analysis. J. Appl. Soc. Psychol. 2000, 30, 2194-2215. [CrossRef]

50. Sturman, M.C. Searching for the inverted U-shaped relationship between time and performance: Meta-analyses of the experience/performance, tenure/performance, and age/performance relationships. J. Manag. 2003, 29, 609-640.

51. Nunnally, J.C. Psychometric Methods; McGraw Hill: New York, NY, USA, 1978.

52. Fornell, C.; Larcker, D.F. Evaluating structural equation models with unobservable variables and measurement error. J. Mark. Res. 1981, 18, 39-50. [CrossRef]

53. Podsakoff, P.M.; MacKenzie, S.B.; Podsakoff, N.P. Sources of method bias in social science research and recommendations on how to control it. Annu. Rev. Psychol. 2012, 63, 539-569. [CrossRef] [PubMed]

54. Lau, R.S.; Cheung, G.W. Estimating and comparing specific mediation effects in complex latent variable models. Organ. Res. Methods 2012, 15, 3-16. [CrossRef] 
55. Hayes, A.F. An index and test of linear moderated mediation. Multivar. Behav. Res. 2015, 50, 1-22. [CrossRef] [PubMed]

56. Shrout, P.E.; Bolger, N. Mediation in experimental and nonexperimental studies: New procedures and recommendations. Psychol. Methods 2002, 7, 422-445. [CrossRef] [PubMed]

57. Hayes, A.F. Introduction to Mediation, Moderation, and Conditional Process Analysis: A Regression-Based Approach; Guilford: New York, NY, USA, 2013.

58. Rego, A.; Leal, S.; Cunha, M.; Faria, J.; Pinho, C. How the perceptions of five dimensions of corporate citizenship and their inter-inconsistencies predict affective commitment. J. Bus. Ethics 2010, 94, 107-127. [CrossRef]

59. Dhanesh, G.S. CSR as organization-employee relationship management strategy: A case study of socially responsible information technology companies in India. Manag. Commun. Q. 2014, 28, 130-149. [CrossRef]

60. Farooq, O.; Payaud, M.; Merunka, D.; Valette-Florence, P. The impact of corporate social responsibility on organizational commitment: Exploring multiple mediation. J. Bus. Ethics 2014, 125, 563-580. [CrossRef]

61. Wang, R.T. Modeling corporate social performance and job pursuit intention: Mediating mechanisms of corporate reputation and job advancement prospects. J. Bus. Ethics 2014, 117, 569-582. [CrossRef]

(C) 2016 by the authors; licensee MDPI, Basel, Switzerland. This article is an open access article distributed under the terms and conditions of the Creative Commons Attribution (CC-BY) license (http://creativecommons.org/licenses/by/4.0/). 